\title{
Estimating design hydrographs at the basin scale: from event-based to continuous hydrological simulation
}

\author{
Estimando hidrogramas de projeto em escala de bacia: de simulações de eventos a \\ simulações contínuas
}

\author{
Ayan Santos Fleischmann ${ }^{1}$, Walter Collischonn ${ }^{1}$ and Rodrigo Cauduro Dias de Paiva ${ }^{1}$ \\ ${ }^{1}$ Universidade Federal do Rio Grande do Sul, Porto Alegre, Brasil \\ E-mails: ayan.fleischmann@gmail.com (ASF),waltercollischonn@gmail.com (WC), rodrigocdpaiva@gmail.com (RCDP)
}

Received: June 28, 2018 - Revised: September 07, 2018 - Accepted: October 27, 2018

\begin{abstract}
Design hydrographs are widely used in practical hydrologic engineering problems. Typical applications adopt event-based (EBM) methods, using rainfall-runoff models to convert design hyetographs into design hydrographs. Uncertainties include the definition of antecedent conditions and the assumption of equivalence between hyetograph and hydrograph return periods. An alternative is to use continuous simulation (CSM) methods, by forcing a rainfall-runoff model with long precipitation series, and directly analyzing the output discharges. To better understand uncertainties in the EBM method and differences between CSM and EBM ones, we applied a hydrological model in the Itajaí-Açu river basin to compare a CSM method with 730 different simulations of an EBM one, considering different basin antecedent conditions and design hyetographs (10- and 50-years). Results indicated that the EBM method leads to a large range of design discharges depending on the antecedent condition. CS-based 10- and 50-years maximum discharges corresponded to percentiles between $30 \%$ and $50 \%$ of the EBM estimates. Higher discharge variation occurred in sub-basins with larger maximum soil water storage. Our conclusions agree with the literature, which points towards CSM-based methods to estimate design discharges.
\end{abstract}

Keywords: Design hydrograph; Continuous simulation; Event-based simulation; Rainfall-runoff model; Hydrological modeling.

\section{RESUMO}

Hidrogramas de projeto são amplamente utilizados em engenharia hidrológica. Típicas aplicações adotam métodos baseados em eventos (EB), utilizando modelos chuva-vazão para converter hietogramas de projeto em hidrogramas. Incertezas incluem a definição de condições antecedentes e a premissa de equivalência entre tempos de retorno da chuva e hidrograma de projeto. Uma alternativa é utilizar métodos de simulação contínua (CS), forçando um modelo chuva-vazão com longas séries de precipitação e analisando diretamente as vazões estimadas. Para melhor compreender as incertezas e diferenças entre os métodos EB e CS, neste estudo aplicou-se um modelo hidrológico na bacia do rio Itajaí-Açu, sendo comparados um método tipo CS com 730 diferentes simulações do tipo EB, variando condições antecedentes e hietogramas de projeto (10 e 50 anos de tempo de retorno). Os resultados indicaram que vazões de projeto muito variadas podem ser obtidas com o método EB, sugerindo uma grande incerteza deste. Vazões máximas de 10 e 50 anos baseadas no método CS corresponderam a percentis entre 30\% e 50\% das estimativas via EB. Por fim, uma maior variação de vazões máximas ocorreu em sub-bacias com maior máximo armazenamento de água no solo.

Palavras-chave: Hidrograma de projeto; Simulação contínua; Simulação de eventos; Modelo chuva-vazão; Modelagem hidrológica. 


\section{INTRODUCTION}

Estimating maximum discharges is a major topic in hydrology, being fundamental for many engineering applications as design of reservoirs and other hydraulic structures and flood control measures and flood risk mapping. Typical estimation methods involve event-based hydrological simulation, with the adoption of a design hyetograph which forces a rainfall-runoff model to yield the design hydrograph (TUCCI, 1998; BOUGHTON; DROOP, 2003).

However, uncertainties exist in this event-based approach, including the definition of antecedent (initial or pre-event) soil moisture state and the hyetograph design itself. This method also assumes an equivalence between return periods of the adopted precipitation and the resulting hydrograph, what may not be always the case (GRIMALDI et al., 2012; HABERLANDT; RADTKE, 2014).

As an alternative to the event-based approach, several authors suggested that design hydrographs and maximum discharges could be obtained by continuous rainfall-runoff simulation (BOUGHTON; DROOP, 2003; LAWRENCE et al., 2014). In this case, a continuous model is forced with a long period precipitation (observed or synthetic) to yield a long term discharge series (CALVER; LAMB, 1995; BOUGHTON; DROOP, 2003). Flood frequency and maximum discharges are derived then from the simulated discharges, by adjusting an empirical distribution to the simulated series. An interesting alternative when long precipitation records do not exist is to use a weather generation algorithm to stochastically generate rainfall series, and then run the continuous model with it (e.g., BLAZKOVA; BEVEN, 2002).

The major benefit of applying a continuous model is to not pre-define an antecedent soil moisture condition, as done in event-based approaches (PAQUET et al., 2013). Furthermore, precipitation records tend to be longer than discharge ones, bringing benefits for continuous simulation methods (BLAZKOVA; BEVEN, 2002). It is neither necessary in continuous simulation to separate storm flow from baseflow, as in many event-based methods (CALVER; LAMB, 1995). Continuous rainfall-runoff models also tend to better represent the hydrological processes occurring within the basin, leading to a more physically based method (FALTER et al., 2016). This alternative is becoming more practicable due to growing computational power, to improvements in rainfall-runoff models and to increase in data availability. However, for practical hydrologic engineering, continuous-based methods are still not a reality, especially in the Brazilian context (CUNHA et al., 2015).

Between event-based and continuous simulation types, Paquet et al. (2013) also cite the semi-continuous methods, which force a continuous rainfall-runoff model with single or multiple design hyetographs to estimate design hydrographs (LAWRENCE et al., 2014). For example, Paquet et al. (2013) present the SCHADEX model, which creates an ensemble of stochastically selected rainfall events and runs a long term continuous simulation model forced with them. In other words, it simulates many events within the continuous model framework, what may be especially relevant in the context of poorly gauged basins, with short precipitation records.
For flood mapping related studies, which usually adopt a design discharge for hydrodynamic simulation (e.g., HEC-HMS/HEC-RAS or MGB/HEC-RAS coupling strategies; see Neto et al. (2015) and Monte et al. (2016)), Grimaldi et al. (2012) proposed an alternative. The methodology involves a $2 \mathrm{D}$ flood inundation hydrodynamic model which is run with a complete time series of simulated runoff from a rainfall-runoff model. The flood hazard map can be created with a statistical computation made pixel-by-pixel within the simulated area.

There are uncertainties in all of the methods. In the event-based ones, errors may arise from the design hyetograph definition itself (ALFIERI et al., 2008), from difficulties in determining the critical rainfall duration for the hyetograph, or the definition of antecedent infiltration losses (GRIMALDI et al., 2012). In continuous simulation applications, there is the sensitivity to model parameters and structure, as well as the adopted rainfall characteristics and distribution, if using a weather generator (BLAZKOVA; BEVEN, 2002). Anyway, it is difficult to define a standard to compare results with (CALVER et al., 2009), and it is generally not possible to define whether a continuous or an event-based design hydrograph method is preferable (BOUGHTON; DROOP, 2003). However, continuous based methods tend to be more coherent since their calibration can be based on a large range of observed events, and there is no need of predefining an initial loss.

There are a few comparisons between event-based and continuous based models for estimating maximum discharges in the literature (BOUGHTON; DROOP, 2003; GRIMALDI et al., 2012; HABERLANDT; RADTKE, 2014), which generally indicate that it should be more interesting to move from event-based toward continuous model methods (GRIMALDI et al., 2012). For relatively large basins (e.g., $>1.000 \mathrm{~km}^{2}$ ), estimating design hydrographs using continuous, distributed rainfall-runoff models may be even more interesting. Recent developments of rainfall-runoff models coupled to hydrodynamic propagation and reservoir routing allow a better representation of the complex basin physical systems (PONTES et al., 2015), and thus a better capacity of design hydrograph estimation.

In this context, we compare a continuous simulation method with an event-based one, both using the same MGB model structure (COLLISCHONN et al., 2007) and the same case study. We also address the uncertainty in the predefinition of antecedent conditions in event-based methods. We use a relatively large basin with important flood impacts to compare design peak discharges computed with both methods, and to discuss the role of floodplains and soil storage parameter on the model responses, as well as differences in discharge estimation across the basin scale.

\section{MATERIAL AND METHODS}

\section{MGB model}

MGB (TUCCI; COLLISCHONN, 2001; COLLISCHONN et al., 2007; PONTES et al., 2017) is a semi-distributed hydrological model which has been widely used in Brazil for water resources management, flood related studies (forecasting, flood risk mapping, 
etc.), understanding of hydrological processes, and evaluation of the impact of land use and climate change.

In the model, the basin is divided into unit-catchments, which are further divided into hydrological response units (HRU's). Within each HRU, a vertical hydrological balance is computed considering canopy interception, soil infiltration, soil/plant evapotranspiration, and surface, sub-surface and groundwater flow generation. The generated flows are routed towards the unit-catchment outlet through linear reservoirs. Then, the routed flows are propagated through the river drainage network using either the Muskingum-Cunge or the inertial (hydrodynamic) method. In this study the inertial method is employed to simulate reservoir and floodplain hydrodynamics.

More details on the MGB model description can be found in Collischonn et al. (2007), Pontes et al. (2015) and Pontes et al. (2017).

\section{Model application in the Itajai- $A$ çu river basin}

The Itajaí-Açu river basin is located in Santa Catarina state, Brazil, and is among the most flood affected basins in Brazil. It is home to around 1.5 million people, where most cities are located on the flat Itajaí-Açu river valley areas, along with relevant rice and other agricultural activities. The basin was used as a case study in this paper due to the relevance of flooding across it, as well as to the existence of peak attenuation by flood control dams and floodplains, what adds further elements to analyze in terms of design hydrographs estimation. There are three large flood-control dams located in the three main basin tributaries, the Itajaí do Norte, Itajaí do Oeste and Itajaí do Sul dams (PINHEIRO; FRANK, 2003).

Following a default MGB application as described by Collischonn et al., (2007) and Pontes et al., (2017), the Itajaí-Açu basin was discretized in 1118 unit-catchments, 11 HRUs (based on combination of soil types and land cover maps by EPAGRI (2018) and eight sub-basins for definition of model parameters (Figure 1). The hydrodynamic parameters adopted were Manning's coefficient 0.03 for the whole basin, and river bankfull width $(B)$ and depth $(H)$ based on a geomorphic relationship with drainage area $(A)$, which were adjusted with local data based on in-situ cross sections (Equations 1 and 2):

$$
\begin{aligned}
& B=0.95 * A^{0.5} \\
& H=0.3 * A^{0.3}
\end{aligned}
$$

Topographic information was extracted from the $1 \mathrm{~m}$ high-resolution Digital Elevation Model (DEM) from SDS (2018), which was upscaled to $30 \mathrm{~m}$ to allow data management and processing.

To take into consideration the flood-control reservoir effects, on the three unit-catchments where the three dams are located, the unit-catchment outflow equation from the Inertial method (PONTES et al., 2015) was replaced by equations describing the

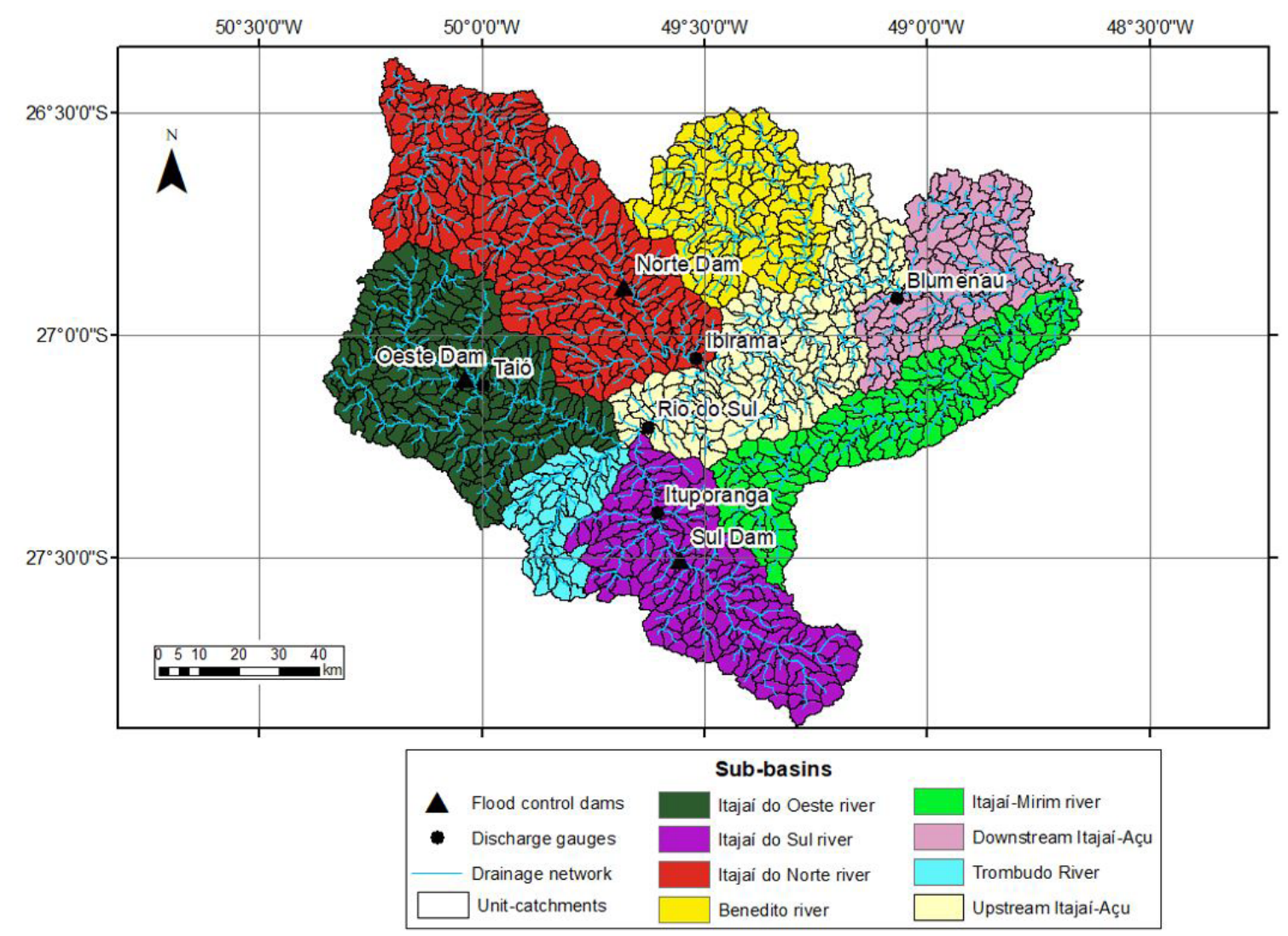

Figure 1. Itajaí-Açu river basin with the adopted eigth sub-basins (one for each main tributary) for model calibration and the 1118 unit-catchments. The five discharge gauges used in model adjustment and the three flood control dams are also presented. 
dam outflow structures (bottom outlet and spillway) as described by Pinheiro and Frank (2003).

We calibrated MGB parameters running the model from 1950 to 2016, forced with observed ANA (Brazilian National Water Agency) precipitation data and INMET (Brazilian National Institute of Meteorology) long term climatology data. The later were obtained from the Indaial gauge, and include the following variables: wind speed, relative humidity, sunlight hours, atmospheric pressure and air temperature. Soil related parameters were calibrated aiming to optimize the simulated flood frequency curves and hydrographs (Nash-Sutcliffe coefficient) in comparison with observations. A similar calibration procedure for estimating maximum discharges were carried out by Paquet et al. (2013). Regarding the flood control reservoirs, they were only considered when they were effectively operating (i.e., 1973, 1976 and 1993 for Itajaí do Oeste, Itajaí do Sul and Itajaí do Norte dams, respectively). Additionally, we considered that all outlet works structures (at the bottom) of the three dams had their gates permanently open. This is reasonable because the three dams have uncontrolled spillways, and because the bottom outlets have low discharge capacity even when completely opened.

\section{Experiment design and continuous simulation of design hydrographs}

In this study, we use the MGB model application in the Itajaí-Açu basin to compare design discharge peaks and hydrographs estimated with two methods: (i) continuous simulation method (CSM): long-term estimation of extreme peak discharges based on an empirical and on a Gumbel distribution based analysis of a long-term model run (1950-2016); and (ii) event-based method (EBM): simulation of design hyetographs positioned in 730 different days (two years) (i.e. 730 different antecedent conditions), in order to evaluate the event-based method uncertainty.

Then, in this paper, we compare hundreds of different realizations of the EBM method with design discharge estimates from the CSM method. For the EBM one, in each of the 730 runs we replaced four days of observed rainfall with four days of the design rainfall, starting at the 4-days period from $1^{\text {st }}$ January 1981 to January $4^{\text {th }} 1981$, following with the four days from January 2 th to January 5 th, and so on. These years are representative of a relatively dry (1981) and a very wet year (1983). Note that this CSM method could also be called a semi-continuous method (PAQUET et al., 2013). The selected periods thus involve a major flood in the basin history, the 1983 flood, and also recession periods, so that a large range of antecedent conditions can be evaluated. The resulted 730 design hydrographs were then analyzed together, by comparing the ensemble of design discharges among them and with the continuous simulation based maximum discharge estimates. A final evaluation is performed at basin scale by looking at the variation of discharge peaks (range and coefficient of variation $-\mathrm{CV}$ ) in different locations.

Figure 2 presents the adopted hourly design hyetographs, with a duration of four days, and intensity and time distribution based on a previous hydrological study in the basin (JICA, 2011). The time distribution was based on the 1984-flood event, and the event intensity on an adjusted exponential distribution. The same

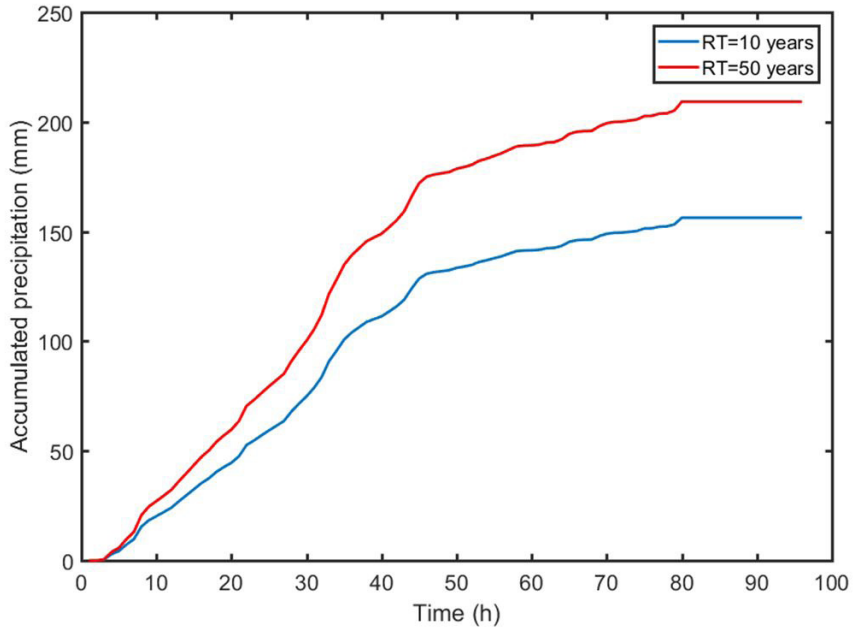

Figure 2. Adopted design hyetographs (accumulated precipitation) for 10 - and 50 -years return periods.

hyetograph was used for the whole basin in order to simplify the analysis. Finally, two different return periods were adopted in the simulations, the 10- and the 50-years floods, which were used for flood hazard assessment at the basin scale by JICA (2011).

\section{RESULTS AND DISCUSSION}

\section{Model adjustment and continuous-based estimation of extreme peak discharges (CSM method)}

The model was adjusted by calibrating the rainfall-runoff model soil parameters, aiming at optimizing flood frequency curves and hydrographs (through Nash-Sutcliffe coefficient) at five main locations in the basin (Figure 3). The curves were derived from the 1950-2016 simulation period and were created by selecting maximum annual discharges and computing the associated empirical probability with the Weibull plotting position equation (as done for example by Grimaldi et al. (2012)). Years with failures during long periods or during major flood events in the observation records were not included in the analysis.

The flood frequency curves in Figure 3 indicate that the continuous simulation model is able to reproduce maximum discharges. Simulated hydrographs are not presented for brevity, and Nash-Sutcliffe coefficients were 0.7 for Ituporanga, 0.7 for Taió, 0.55 for Ibirama, 0.83 for Rio do Sul and 0.57 Blumenau, which can also be considered satisfactory. While Ituporanga and Ibirama gauges are located in non-floodplain regulated sub-basins, the other ones are downstream of relevant floodplains areas.

Results presented in Figure 3 could be used to estimate extreme peak discharges, e.g., the 2-, 10-, and 50-years floods. In this analysis, high return periods (50-years) are uncertain, given the relatively short simulation period ( 66 years). To estimate such high peak discharges (e.g., a 10000-years flood), a longer simulation period could be performed using weather generation algorithms (e.g., BLAZKOVA; BEVEN, 2002). According to Boughton and Droop (2003), if a long precipitation record is available, it 

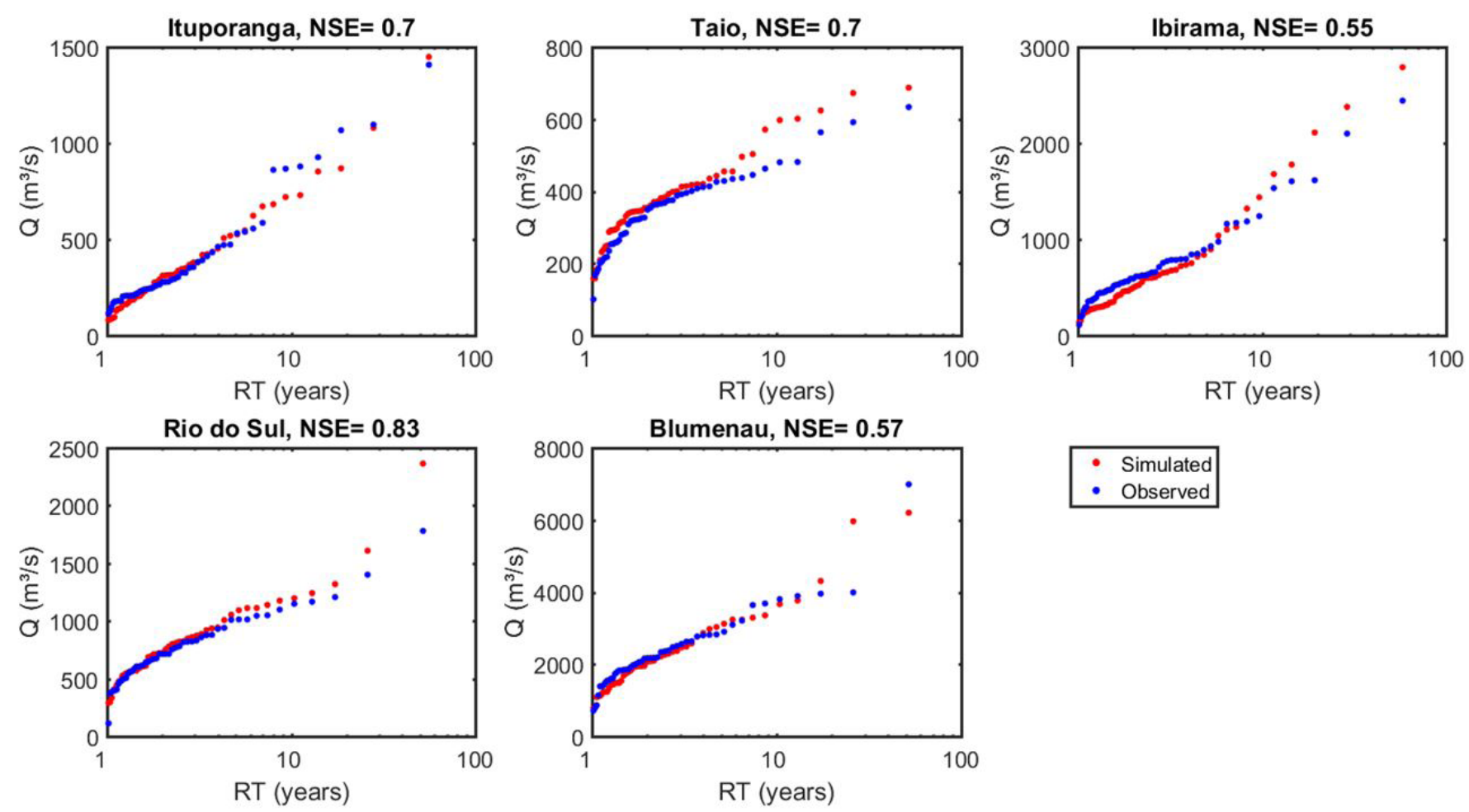

Figure 3. Model adjustment to maximum annual discharges (flood frequency curves) for the gauges Ituporanga, Taio, Ibirama, Rio do Sul and Blumenau. Nash-Sutcliffe Efficiency (NSE) values for the respective hydrographs are presented in graph titles.

is preferable to derive flow peaks with continuous methods in comparison to event-based ones. Additionally, if design hydrograph is desired (and not only the flow peak), a hydrograph shape and volume would also need to be defined.

\section{Simulated design hydrographs with different antecedent conditions (EBM method)}

Figure 4 presents an example of simulated design hydrographs with the EBM method at Rio do Sul gauge location, considering that the 50-years hyetograph would occur in different days from June/1983 to October/1983. The thick black line shows the simulation without design hyetographs, which reflects the initial condition for each simulated design hydrograph. Results show a high sensitivity of the model outputs to the adopted timing of the design rainfall, since discharge peaks vary (in the displayed June/1983 - October/1983 period) from less than $1500 \mathrm{~m}^{3} / \mathrm{s}$ to more than $3500 \mathrm{~m}^{3} / \mathrm{s}$. The highest estimated peak discharge would occur if the design hyetograph replaced the observed precipitation in $12^{\text {th }}$ July 1983 , just after intense precipitation effectively occurred in the basin, yielding a $3677 \mathrm{~m}^{3} / \mathrm{s} 50$-years design discharge.

Ensembles of the 730 simulated design hydrographs (EBM method) are presented in Figure 5 and Figure 6 for different locations for the 10 - and 50 -years events, together with the CSM flood peak based estimates (horizontal black line). A Gumbel distribution was satisfactorily adjusted $(\mathrm{P}<0.05$ with Kolmogorov-Smirnov test) to the long term simulation discharge series to derive the 10 (50)-years discharges, yielding 671 (1012),

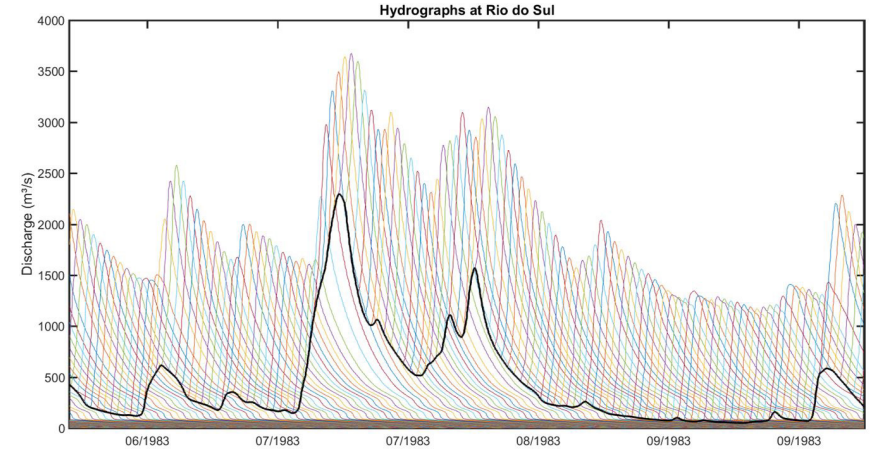

Figure 4. Multiple 50-year events simulated in different days (i.e. different antecedent conditions). Results are presented only for months close to the July 1983 flood. The original simulation without design hyetograph is highlighted in black, which indicates the basin antecedent conditions.

494 (635), 997 (1489), 1371 (1918) and 3638 (4957) $\mathrm{m}^{3} / \mathrm{s}$ for the gauges Ituporanga, Taió, Ibirama, Rio do Sul and Blumenau, respectively.

Results from the event-based method in Figures 5 and 6 indicate a large spread of design discharges depending on the days the design rainfall replaced the observed precipitation, which varies the antecedent soil moisture and river/reservoir storage conditions, for both 10 - and 50 -years events.

Table 1 summarizes peak flows obtained with the CSM (peak flow) and EBM (range and CV) methods. A large range of peak flows is observed for both return periods and 

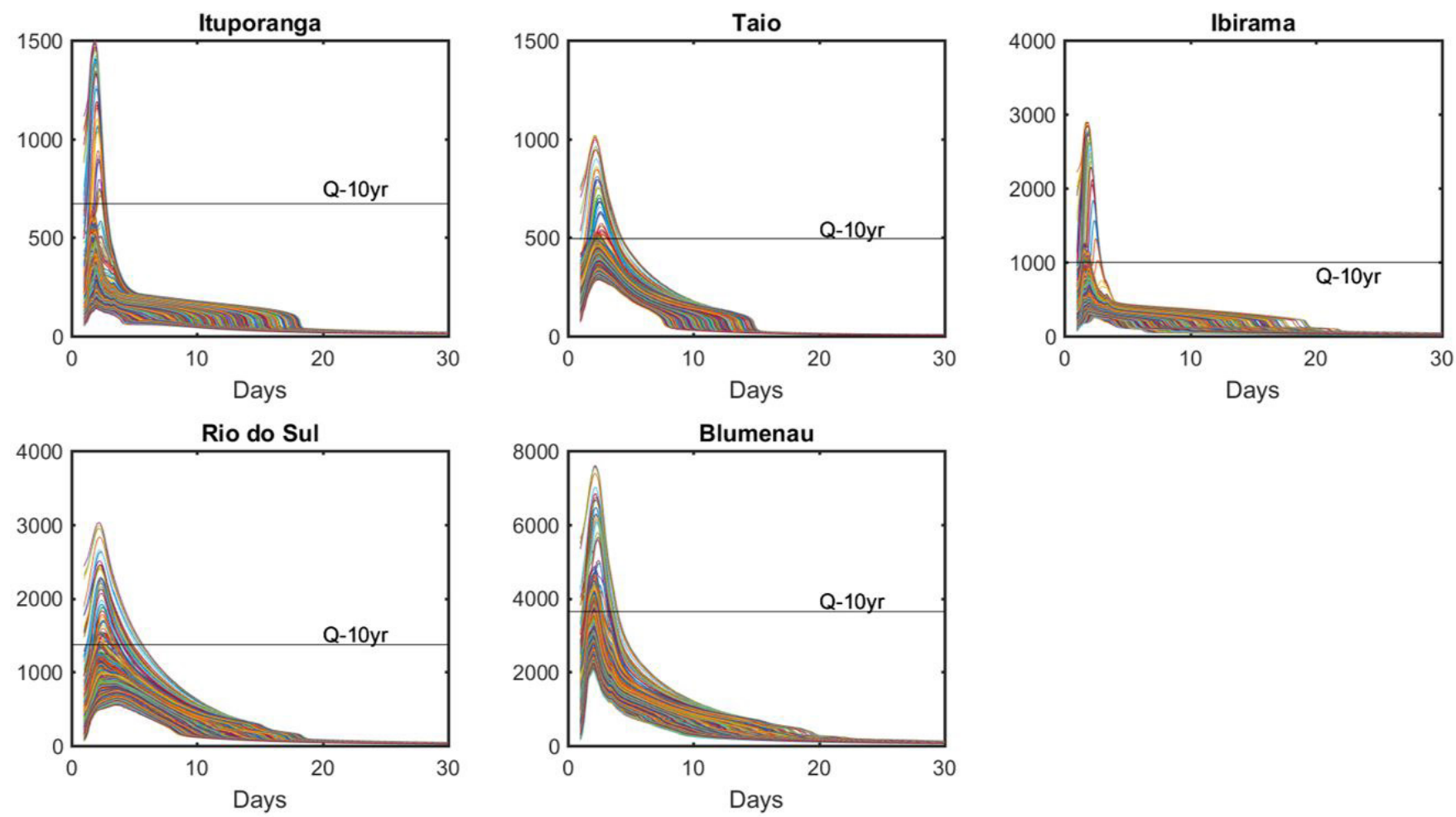

Figure 5. All simulated 10-years design hydrographs obtained with the event-based method for the locations of Ituporanga, Taio, Ibirama, Rio do Sul and Blumenau gauges. The 10-years peak discharge derived from the long term continuous simulation is presented as a horizontal line for comparison purposes.
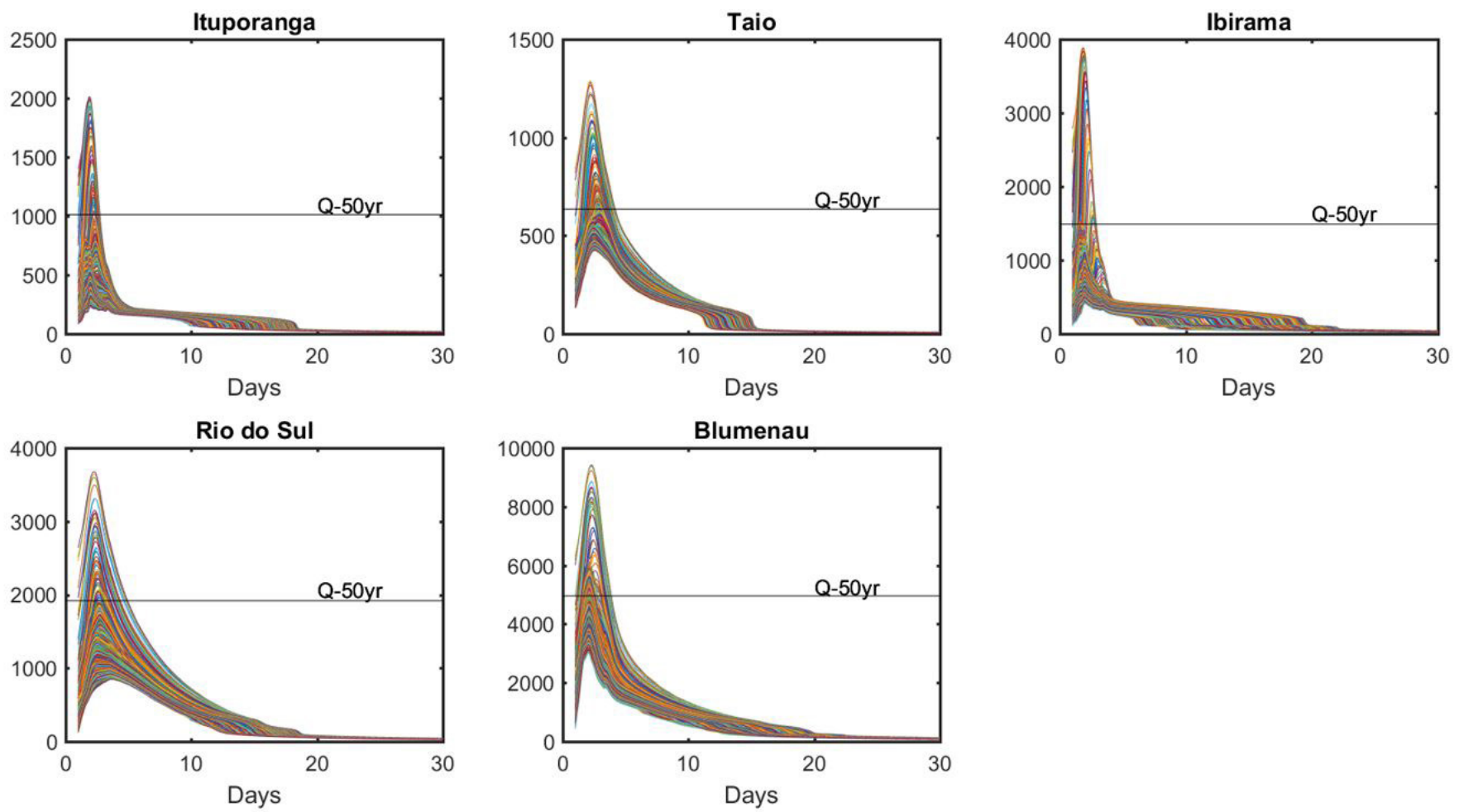

Figure 6. All simulated 50-years design hydrographs obtained with the event-based method for the locations of Ituporanga, Taio, Ibirama, Rio do Sul and Blumenau gauges. The 50-years peak discharge derived from the long term continuous simulation is presented as a horizontal line for comparison purposes. 
More interestingly, 10-years (50-years) CSM flood peaks corresponded to the percentiles $47 \%$ (42\%), 44\% (36\%), 43\% (47\%), 44\% (41\%) and 35\% (31\%) of the EBM estimated values for Ituporanga, Taió, Ibirama, Rio do Sul and Blumenau, respectively (Table 1). These numbers provide an interesting interpretation of the model estimated design discharges. However, one must notice that these numbers cannot be used as a rule of thumb to estimate design discharges from an ensemble of simulated design hydrographs, since in this study we only evaluated two contrasting years (1981 and 1983). Actually, given the very extreme nature of the 1983 wet year, typical years in the basin tend to be more similar to the 1981 one. Model results suggest that one must be very careful in adopting the initial conditions for the simulation of a design hydrograph: the uncertainties are high, even considering only two years of simulation. Even then, these results suggest that an intermediate (e.g., a median) ensemble member could be used to estimate a 10 - or 50-years design hydrograph.

The shape of the design hydrograph is also relevant. In this MGB model application, two main attenuation factors affect the output hydrograph shape beside the runoff-generation mechanism itself, namely the floodplains and flood control reservoirs. The effect of the latter can be seen in the post-event release of stored water in the reservoirs, especially in Ituporanga, Taió and Ibirama, which are located downstream from one dam each.

A basin scale analysis is carried out to evaluate design peak discharges variations in different locations. Figure 7 (for 10-years) and Figure 8 (50-years) present the relationship between drainage area and $\mathrm{CV}$ of maximum discharges for each unit-catchment in the basin. For each one, a sample of 730 peak discharges is available for this analysis. The unit-catchments points are further classified in terms of the sub-basins where they are located, i.e. Itajai do Norte, Itajaí do Sul, Itajaí do Oeste and Itajaí-Açu (mainstem) river sub-basins. For both 10 - and 50 -years there is a general trend of decreasing CV with drainage area for the Sul and Norte sub-basins (red and green points), while Oeste and mainstem do not present a clear relationship. More interestingly, there is a distinction in CV values among the different sub-basins: Mainstem unit-catchments present the lowest values, while the Norte ones tend to present the highest ones. This can be explained by the different soil storage parameters associated to each sub-basin. After model calibration, the mainstem and Sul sub-basins presented a smaller maximum soil water storage parameter value (i.e. parameter Wm, see Tucci and Collischonn, (2001) for discussion) than the other two. The average calibrated $\mathrm{Wm}$ values were $50 \mathrm{~mm}$ for mainstem, $108 \mathrm{~mm}$ for Oeste, $224 \mathrm{~mm}$ for Sul and $448 \mathrm{~mm}$ for Norte sub-basins, what is the same increasing order of $\mathrm{CV}$ values. Higher soil water storage leads to higher variation in the estimated

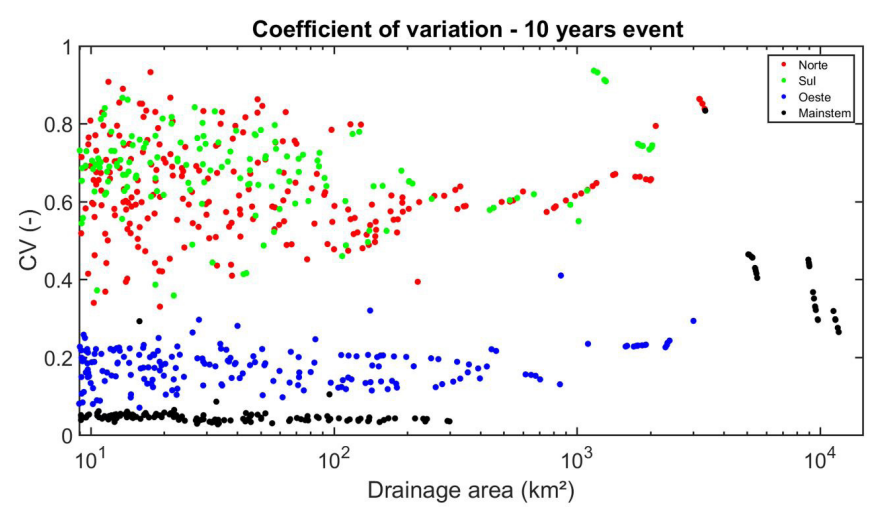

Figure 7. Relationship between drainage area and coefficient of variation of 10-years maximum peak discharges for each unit-catchment of the basin. The points are colored according to the respective unit-catchment sub-basin: Norte (Itajaí do Norte), Sul (Itajaí do Sul), Oeste (Itajaí do Oeste) and mainstem (Itajaí-Açu).

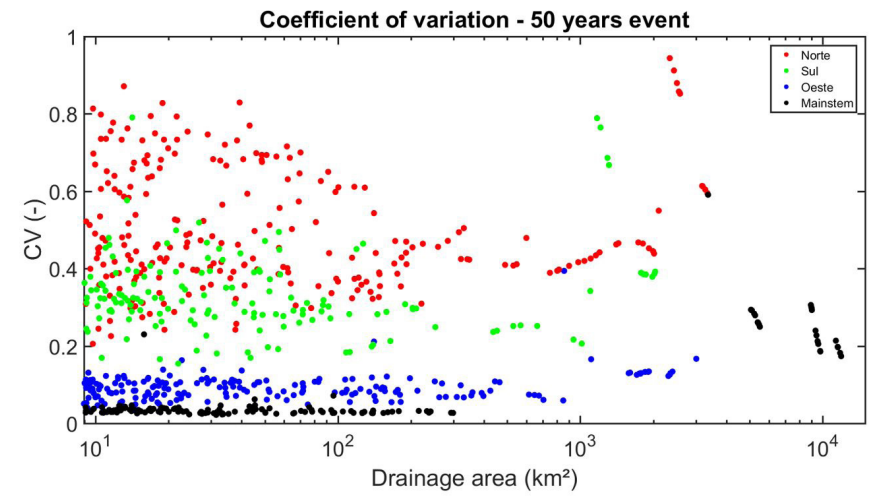

Figure 8. Relationship between drainage area and coefficient of variation of 50 -years maximum peak discharges for each unit-catchment of the basin. The points are colored according to the respective unit-catchment sub-basin: Norte (Itajaí do Norte), Sul (Itajaí do Sul), Oeste (Itajaí do Oeste) and mainstem (Itajaí-Açu).

Table 1. Summary of the comparison between continuous simulation (CSM) and event-based (EBM) methods, in terms of 10- and 50-years peak discharge $\left(\mathrm{Q}_{\mathrm{p}}\right)$ and coefficient of variation $(\mathrm{CV})$. The percentiles of CSM peak flows corresponding to the EBM ensemble values are presented in the two final rows.

\begin{tabular}{ccccccc}
\hline & & Ituporanga & Taió & Ibirama & Rio do Sul & Blumenau \\
\hline CSM & 10 -years $Q_{\mathrm{p}}\left(\mathrm{m}^{3} / \mathrm{s}\right)$ & 671 & 494 & 997 & 1371 & 3638 \\
& 50 -years $\mathrm{Q}_{\mathrm{p}}\left(\mathrm{m}^{3} / \mathrm{s}\right)$ & 1012 & 635 & 1489 & 1918 & 4957 \\
EBM & 10 -years $\mathrm{Q}_{\mathrm{p}}$ range $\left(\mathrm{m}^{3} / \mathrm{s}\right)$ & $139-1498$ & $284-1018$ & $246-2895$ & $548-3026$ & $2035-7596$ \\
& 10 -years CV $(-)$ & 0.75 & 0.22 & 0.83 & 0.46 & 0.26 \\
& 50 -years $\mathrm{Q}_{\mathrm{p}}$ range $\left(\mathrm{m}^{3} / \mathrm{s}\right)$ & $227-2015$ & $422-1287$ & $408-3888$ & $845-3676$ & $3016-9416$ \\
CSM X EBM & 50 -years CV $(-)$ & 0.39 & 0.13 & 0.59 & 0.29 & 0.17 \\
(percentile) & 10 -years $(\%)$ & 47 & 44 & 43 & 44 & 31 \\
\hline
\end{tabular}



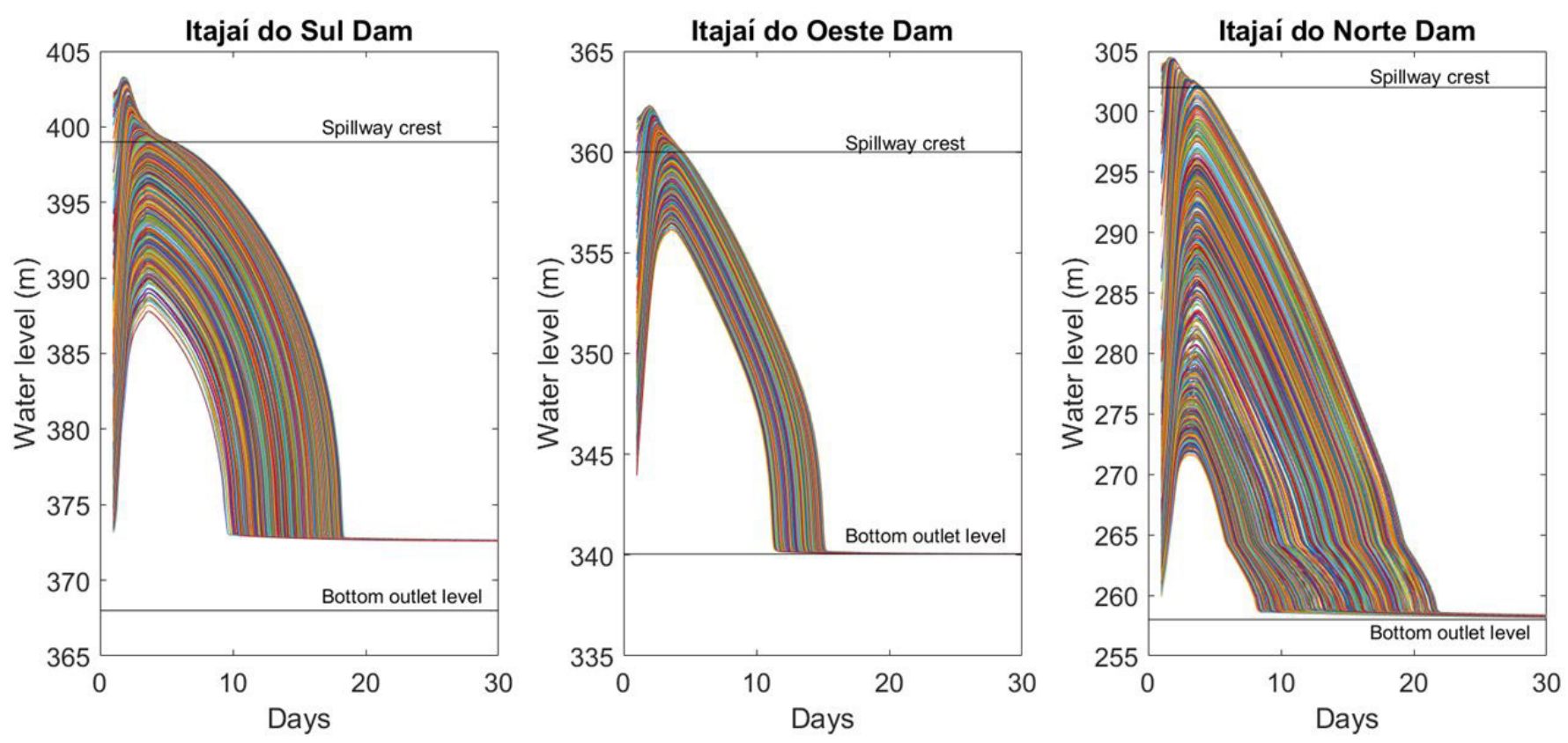

Figure 9. All simulated 50-years design water level series for the Itajaí do Sul, Itajaí do Oeste and Itajaí do Norte dams. Spillway crests and bottom outlet levels are also displayed.

design peak discharges, since there is a broader range of possible water storage states in these sub-basins.

The 10-years CV values were generally higher than the 50 -years ones. This possibly occurred because the effect of antecedent soil water storage becomes less important during large floods.

The Itajaí-Açu river basin has three flood control dams, which were explicitly simulated in the hydrologic-hydrodynamic modeling framework adopted in this study. A final test was performed to investigate the influence of different antecedent conditions on the simulated water levels in each reservoir. Figure 9 presents the 730 50-years events for the Itajaí do Sul, Itajaí do Oeste and Itajaí do Norte dams. Results show that a few events would be able to reach the spillway crests in the dams. These events would occur if the design hyetograph occurred in the wettest period of the whole simulation period, and would certainly relate to a much higher return period than the estimated 50 -years. However, it is noticeable that, as observed for the simulated hydrographs in previous figures, a large range of simulated reservoir water levels was obtained. Values varied from 387 to $403 \mathrm{~m}$ in Itajaí do Sul dam, 356 to $632 \mathrm{~m}$ in Itajaí do Oeste dam, and 272 to 304 in Itajaí do Norte dam.

Finally, in this study we used a distributed, coupled hydrologic-hydrodynamic model, which is more suitable than simpler methods to simulate complex river-floodplain systems as the Itajaí-Açu river basin. In this case study, together with floodplain and flood-control dams attenuation, other relevant hydraulic processes influence the flood wave propagation, such as backwater effects and timing of different tributaries. Hydrodynamic processes alter the basin hydrograph shape in a significant manner and should be taken into account in any method to estimate basin scale design discharges, and the tools for this task are already available. It is important to notice that antecedent conditions in such hydrologic-hydrodynamic model applications do not involve only prior soil water storage, but also channel water storage and the associated backwater effects.

\section{CONCLUSION}

We compared two different methods to estimate design hydrographs, based on a continuous simulation model (CSM) and on an event-based one (EBM). Results indicated that a large range of possible design discharges could be obtained depending on the adopted antecedent conditions, so that the uncertainty in EBM is very high. Results for simulated reservoir water level yielded similar conclusions.

By comparing continuous-based and event-based methods, the 10- and 50-year discharge estimates from the former corresponded to percentiles between $30 \%$ and $50 \%$ of the ensemble (730 members) of event-based peak discharges. This shows that, for this case, an intermediate antecedent condition would equal both methods, what is an important conclusion for practical hydrological engineering applications.

To investigate results at the basin scale, the coefficient of variation of event-based discharge estimates were evaluated for each unit-catchment, and showed a direct relationship between maximum soil water storage and discharge variation. Sub-basins with larger maximum storage showed larger variation, while sub-basins with smaller storage showed a much smaller one. Larger floods (i.e. the 50 -years event) led to smaller CV values than smaller floods (i.e. the 10 -years event) because during larger events (i.e. larger volumes) soil tends to be rapidly saturated.

Our results are in agreement with the literature, and suggest that a continuous simulation method could be used in practical hydrological engineering, given the recent improvements 
in hydrological modeling capabilities and computational power. Future studies could involve evaluating model uncertainties (BLAZKOVA; BEVEN, 2002; ZENG et al., 2016), as well as the shape and distribution of design hyetographs (e.g., Grimaldi et al., 2012). We also did not consider a possible nonstationarity of discharges existent in the Itajaí-Açu basin, although some studies have suggested its existence in Southern Brazil (e.g., Bartiko et al. (2017)), and this suggests further developments for this topic.

\section{ACKNOWLEDGEMENTS}

The first author would like to thank CNPq for funding this research.

\section{REFERENCES}

ALFIERI, L.; LAIO, F.; CLAPS, P. A simulation experiment for optimal design hyetograph selection. Hydrological Processes, v. 22, n. 6, p. 813-820, 2008.

BARTIKO, D.; CHAFFE, P.L.B.; BONUMÁ, N.B. Nonstationarity in maximum annual daily streamflow series from Southern Brazil. Revista Brasileira de Recursos Hidricos, v. 22, 2017.

BLAZKOVA, S.; BEVEN, K. Flood frequency estimation by continuous simulation for a catchment treated as ungauged (with uncertainty). Water Resources Research, v. 38, n. 8, p. 14-1-14-14, 2002. http://dx.doi.org/10.1029/2001WR000500.

BOUGHTON, W.; DROOP, O. Continuous simulation for design flood estimation - a review. Environmental Modelling \& Software, v. 18, n. 4, p. 309-318, 2003.

CALVER, A.; LAMB, R. Flood frequency estimation using continuous rainfall-runoff modelling. Physics and Chemistry of the Earth, v. 20, n. 5-6, p. 479-483, 1995.

CALVER, A.; STEWART, E.; GOODSELL, G. Comparative analysis of statistical and catchment modelling approaches to river flood frequency estimation. Journal of Flood Risk Management, v. 2, n. 1, p. 24-31, 2009. http://dx.doi.org/10.1111/j.1753318X.2009.01018.x.

COLLISCHONN, W.; ALLASIA, D.; SILVA, B. C.; TUCCI, C. E. The MGB-IPH model for large-scale rainfall-runoff modelling. Hydrological Sciences Journal, v. 52, n. 5, p. 878-895, 2007.

CUNHA, S. F.; SILVA, F. E. O.; MOTA, T. U.; PINHEIRO, M. C. Avaliação da acurácia dos métodos do SCS para cálculo da precipitação efetiva e hidrogramas de cheia. Revista Brasileira de Recursos Hídricos, v. 20, n. 4, p. 837-848, 2015. http://dx.doi. org/10.21168/rbrh.v20n4.p837-848.

FALTER, D.; DUNG, N. V.; VOROGUSHYN, S.; SCHRÖTER, K.; HUNDECHA, Y.; KREIBICH, H.; APEL, H.; THEISSELMANN, F.; MERZ, B. Continuous, large-scale simulation model for flood risk assessments: proof-of-concept. Journal of Flood Risk Management, v. 9, n. 1, p. 3-21, 2016. http://dx.doi.org/10.1111/jfr3.12105.

GRIMALDI, S.; PETROSELLI, A.; SERINALDI, F. Design hydrograph estimation in small and ungauged watersheds: continuous simulation method versus event-based approach. Hydrological Processes, v. 26, n. 20, p. 3124-3134, 2012.

HABERLANDT, U.; RADTKE, I. Hydrological model calibration for derived flood frequency analysis using stochastic rainfall and probability distributions of peak flows. Hydrology and Earth System Sciences, v. 18, n. 1, p. 353-365, 2014. http://dx.doi.org/10.5194/ hess-18-353-2014.

JICA - AGÊNCIA DE COOPERAÇÃO INTERNACIONAL DO JAPÃO. Estudo Preparatório para o Projeto de Prevenção e Mitigação de Desastres na Bacia do Rio Itajaí. Relatório Final. Novembro de 2011. Santa Catarina: JICA, 2011.

LAWRENCE, D.; PAQUET, E.; GAILHARD, J.; FLEIG, A. K. Stochastic semi-continuous simulation for extreme flood estimation in catchments with combined rainfall-snowmelt flood regimes. Natural Hazards and Earth System Sciences, v. 14, n. 5, p. 1283-1298, 2014.

MONTE, B. E. O.; COSTA, D. D.; CHAVES, M. B.; MAGALHÃES, L. D. O.; UVO, C. B. Hydrological and hydraulic modelling applied to the mapping of flood-prone areas. Revista Brasileira de Recursos Hídricos, v. 21, n. 1, p. 152-167, 2016.

NETO, A. R.; CIRILO, J. A.; DANTAS, E. O.; SILVA, E. R. Caracterização da formação de cheias na bacia do rio Uno em Pernambuco: simulação hidrológica-hidrodinâmica. Revista Brasileira de Recursos Hidricos, v. 20, n. 2, p. 394-403, 2015.

PAQUET, E.; GARAVAGLIA, F.; GARÇON, R.; GAILHARD, J. The SCHADEX method: A semi-continuous rainfall-runoff simulation for extreme flood estimation. Journal of Hydrology, v. 495, p. 23-37, 2013. http://dx.doi.org/10.1016/j.jhydrol.2013.04.045.

PINHEIRO, A.; FRANK, B. Obras de controle de cheias. In: FRANK, B.; PINHEIRO, A. Enchentes na Bacia do Itajaí: 20 anos de experiência. Blumenau: Edifurb, 2003. cap. 7, p. 143-172.

PONTES, P. R. M.; FAN, F. M.; FLEISCHMANN, A. S.; PAIVA, R. C. D.; BUARQUE, D. C.; SIQUEIRA, V. A.; COLLISCHONN, W. MGB-IPH model for hydrological and hydraulic simulation of large floodplain river systems coupled with open source GIS. Environmental Modelling \&o Software, v. 94, p. 1-20, 2017.

PONTES, P. R.; COLLISCHONN, W.; FAN, F. M.; PAIVA, R. C.; BUARQUE, D. C. Modelagem hidrológica e hidráulica de grande escala com propagação inercial de vazões. Revista Brasileira de Recursos Hidricos, v. 20, n. 4, p. 888-904, 2015. http://dx.doi. org/10.21168/rbrh.v20n4.p888-904.

TUCCI, C. E. Modelos hidrológicos. Porto Alegre: UFRGS, 1998. 
TUCCI, C.; COLLISCHONN, W. Simulação hidrológica de grandes bacias. Revista Brasileira de Recursos Hídricos, v. 6, n. 1, p. 95-118, 2001. http://dx.doi.org/10.21168/rbrh.v6n1.p95-118.

ZENG, Q.; CHEN, H.; XU, C. Y.; JIE, M. X.; HOU, Y. K. Feasibility and uncertainty of using conceptual rainfall-runoff models in design flood estimation. Hydrology Research, v. 47, n. 4, p. $701-717,2016$.

\section{Authors contributions}

Ayan Santos Fleischmann: Performed the simulation tests and worked on the manuscript writing.

Walter Collischonn: Assisted the experimental design delineation and revised the manuscript.

Rodrigo Cauduro Dias de Paiva: Assisted the experimental design delineation and revised the manuscript. 